ZOOLOGIA 32(5): 409-422, October 2015

http://dx.doi.org/10.1590/S1984-46702015000500010

\title{
Four new species of Cosmetus from Panama, with comments on the systematics of the genus (Opiliones: Cosmetidae)
}

\author{
Amanda Coronato-Ribeiro ${ }^{1} \&$ Ricardo Pinto-da-Rocha ${ }^{1}$
}

\author{
'Departamento de Zoologia, Instituto de Biociências, Universidade de São Paulo. Caixa Postal 11461, 05422-970 São \\ Paulo, SP, Brazil. E-mails: amandacoronato@hotmail.com; ricrocha@usp.br
}

\begin{abstract}
Four new sympatric species of Cosmetus Perty, 1833 are described from "Reserva Natural Privada Burbayar, Provinciar Panamá, Panamá" (male holotypes deposited in MIUP). Cosmetus balboa sp. nov. can be distinguished by the combinations of following features: smooth ocularium, larger distal tubercle on pedipalpal femur, coxa I with large ventral tubercle directed upwards, coxa IV with one large dorsoproximal tubercle, two geminate (from base) dorsoapical tubercles with blunt apex. Cosmetus burbayar sp. nov., can be distinguished from other species of the genus by the irregular and discontinuous shape of its yellow spot, extending from lateral anterior to posterior margins and invading prosoma, areas I-III and free tergites. Cosmetus pollera sp. nov. can be distinguished from congeners by two small yellow and two large pairs of spots on prosoma and two other spots on posterior margin of dorsal scutum. Cosmetus tamboritos sp. nov. is distinguished from other species of the genus by the following combinations of characters: having two retrolateral apical tubercles on bulla, one being double size of other; coxa IV lacks patches of a cluster of four tubercles on dorsolateral proximal region and two pointed tubercles fused at their apices; and femur IV with bifid retrolateral apical tubercle. The penis of Cosmetus arietinus (Mello-Leitão, 1940) and C. variolosus Mello-Leitão, 1942 are described for the first time. A table with the main diagnostic features of Cosmetus species is given. We suggest that the spine of area III, sexually dimorphic chelicerae and posterior legs, and pigmentation of dorsal scutum are good diagnostic features at species level.
\end{abstract}

KEY WORDS. Cosmetinae; harvestmen; systematics; taxonomy.

Among harvestmen, Cosmetidae is the second most diverse family of the suborder Laniatores, with more than 700 species (Kury 2003, 2011, 2013). They occur from southern United States of America to southern South America (with exception of Chile) (Kuny 2003, 2009). However, the greatest species richness is recorded from tropical forests of Central and South America and from the Andes (PinTo-DA-Rocha \& YamaguTI 2013). Adult Cosmetidae can be easily recognized by the spoonshaped pedipalps, in which the lateral compression of femoratibiae covers the chelicerae (Kury \& PINTO-DA-Rocha 2007). Roewer (1912) divided the family in two subfamilies, based on the armature of claws III and IV: Cosmetinae, with smooth claws, composed of 680 species and 116 genera, and Discosomaticinae, with pectinate claws, including 29 species and 10 genera (Kury 2003, 2009, Kury \& Pinto-Da-Rocha 2007, PINTO-DA-Rocha \& Hara 2011). Using the morphology of the claws for dividing cosmetids into two subfamilies has been rejected since Ringuelet (1959). The smooth claws seem to be a plesiomorphic character, however there is no other character to support the monophyly of Cosmetinae and no hypothesis on how the pectinated claws evolved within the family (FERREIRA $\&$ KuRY 2010). Since no cladistics hypothesis has been advanced for the internal relationships of cosmetids, it is impossible to understand the evolution of this feature, and the validity and composition of Discosomaticinae (FERREIRA \& KURY 2010).

Carl F. Roewer proposed a system of classification for cosmetid genera based mainly on a combination of armature of dorsal scutum (e.g. areas, anal operculum) and number of tarsal segments (RoEwER 1916, 1923, 1927, 1947). However, the number of articles is highly variable, even within the same species (see Mello-Leitão 1933, Kuny et al. 2007, Pinto-da-Rocha \& Yamaguti 2013). The "Roewerian system" led to the inclusion of several species in unrelated genera, and the erection of dozens of monotypic genera and several similar genera (see Kuny 2003). An attempt to review this system was made by Goodnight \& Goodnight (1953), who studied intraspecific variation in Mexican Cosmetinae, and concluded that tarsus I is less variable than the tarsi of other legs and that it can be used to define genera. However, evidence in support of their classification is not consistent and for this reason it has not been accepted by other researchers (KuRY 2009). In the last 25 years, a few new contributions on the taxonomy of cosmetids have revealed new features that could be useful, such as the morphology of the penis, a structure that can provide characters

2015 | Sociedade Brasileira de Zoologia | www.sbzoologia.org.br | www.scielo.br/zool All content of the journal, except where identified, is licensed under a Creative Commons attribution-type BY. 
for the recognition of genera and species (Avram \& SoAres 1983, Gonzalez-Sponga 1992, 1998, Kury et al. 2007, Kury \& Ferreira 2012, Pinto-Da-Rocha \& Hara 2011, Pinto-da-Rocha \& Yamaguti 2013, Soares \& Soares 1987, Townsend et al. 2010). However, only a few cosmetid genera can be recognized using genitalic and somatic features (see Ferreira \& Kury 2010, Pinto-DA-Rocha \& Hara 2011, Kury \& Barros 2014). As a result almost half of the cosmetid genera are monotypic or are defined by a combination of few features (KurY \& BARRos 2014).

The genus Cosmetus Perty, 1833 is a good example of how problematic is the classification of the family. PICKARD-CAMBridge (1905) designated Cosmetus varius Perty, 1833 as its type species. After that, a few species were added to Cosmetus by authors such as Gervais (1842, 1844), Sørensen (1884), КосH (1839), and SimOn (1880). The original concept of the genus, by PERTY (1833), was similar to that of the family until 1839, when Косн (1839) described the following new genera: Cynorta, Flirtea, Gnidia and Paecilaema. The author included in them species previously assigned to Cosmetus (see Pickard-Cambridge 1904, Kury 2003, Kury et al. 2007). Finally, Kury (2003) synonymized, within Cosmetus, all cosmetid genera with unpaired armature on area III (single or geminated spines), lateral margin of scutum without constriction, ocularium flattened and legs unarmed. The list of synonyms includes seven genera: Cosmetigryne Roewer, 1916; Cosmetellus Roewer, 1927; Belemnometus MelloLeitão, 1940; Procosmetus Mello-Leitão, 1942; Vervloetia Soares \& Soares, 1946; Cosmetiplus Roewer, 1947; and Orthogryne Avram \& Soares, 1983 (KuRY 2003).

Currently, Cosmetus includes 17 species that are distributed from Panama to northern South America (Venezuela, Ecuador, Colombia, Peru and Brazil) (KurY 2003).

The main goal of this paper is describe four sympatric new species of Cosmetus, from central Panama, the northern border of its distribution. Additionally we make some comparisons with other species of the genus in order to contribute towards the classification of the group.

\section{MATERIAL AND METHODS}

The material examined is deposited in the following institutions (acronyms and curators between parentheses): Museo de Invertebrados G.B. Fairchild, Universidad de Panamá (MIUP, D. Quintero), Museu Nacional, Universidade Federal do Rio de Janeiro, Rio de Janeiro (MNRJ, A.B. Kury) and Museu de Zoologia da Universidade de São Paulo, São Paulo (MZSP, R. Pinto-da-Rocha).

All measurements are given in millimeters. Measurements of appendages are from the right side of specimens. Illustrations were made using a Leica MZ APO stereomicroscope with a camera lucida and microscope ZEISS Axioskop 2 Plus. The description of the dorsal armature followed DASILVA \& GNASPINI (2009).

The male genitalia were prepared according to PINTO-DARосна (1997). Nomenclature of genitalic description followed
KuRY \& Villarreal (2015). Descriptions of the external morphology of females only contain information on features that differ from the male.

Table 1 shows a set of characters that are useful to identify Cosmetus species. It is based on the material described herein, as well as literature and other museum specimens examined. The illustrations of the male genitalia of C. arietinus (Mello-Leitão, 1940) and C. variolosus Mello-Leitão, 1942 were made from specimens deposited in the MZSP (numbers 14038 and 238, respectively) Fields (-) indicate lack of information, in literature or unknown male.

Additional material examined. Cosmetus arietinus (MelloLeitão, 1940) (MNRJ 58202 holotype) from Brazil, Espírito Santo: Goitacazes, collected between $1936 / 1937$ by E. May and M. Rosa; (MZSP 14038) from Brazil, Espirito Santo, Linhares ("Reserva Florestal Linhares"), collected in VIII/1992 by M.M. Argel-de-Oliveira; Cosmetus pulcher Goodnight \& Goodnight, 1942 (MNRJ 08268) from Panama, Barro Colorado Island, collected in 2007 by A. Anker; Cosmetus variolosus Mello-Leitão, 1942 (MZSP 238) from Brazil, Espirito Santo, Colatina (São José River), collected in 26/IX/1942 by B. Soares; Cosmetus varius Perty, 1833 (MNRJ 2281) from Brazil, Bahia, collected in 09/V/ 2008 by T. Barnabé.

\section{TAXONOMY}

\section{Cosmetus pollera sp. nov.}

Figs. 1, 5, 9, 13-15, 31

Diagnosis. Cosmetus pollera sp. nov. is similar to $C$. variolosus Mello-leitão, 1942 by the median pair of large spots on posterior prosoma and area I of dorsal scutum (see MelloLeITÃo 1942: 4). The new species (Fig. 1) can be distinguished by two small yellow spots, anterior to large ones, on prosoma and two other spots on posterior margin of dorsal scutum (C. variolosus does not have the small spots and granulations are yellow, see Mello-Leitão 1942: 4, fig. 2); area II smooth (C. variolosus posseses all dorsal scutum irregularly granulated, see Mello-Leitão 1942: 4, fig. 2); coxa IV with distal tubercle wide, short and blunt (C. variolosus with an enlarged tubercle, see MelloLEITÃo 1942: 4, fig. 2); distal margin of penial ventral plate with strong V-cleft, with seven pairs of setae on penial lateral margin (Figs. 14 and 15); stylus flattened, serrate caruncle low and restricted to apex (Figs. 13 and 14) (C. variolosus has distal margin of penis slightly concave, with five pairs of setae and serrate caruncle of stylus with long projections on apex, Figs. 28-30).

Description. Male (holotype). Measurements: Dorsal scutum: length: 4.1, width: 3.75; Prosoma: length: 1.55, width: 2.9; Interocular distance: 1.0; Chelicera: 2.6; Pedipalp: 6.25, femur: 2.0; Legs I: 16.7, II: 39.4, III: 23.0, IV: 31.3; Femur IV: 9.0.

Dorsum (Figs. 1, 31). Dorsal scutum shape type beta (KuRY et al. 2007). Anterior margin smooth. Central paracheliceral projection directed upwards, lateral projection frontwards. Lateral margin smooth, with small projection lateral to the 
Table 1. Diagnostic characters for the 21 species of Cosmetus. Abbreviations used (TUB) tubercles; (AM) anterior margin; (LM) lateral margin; (EM) external margin; (PM) posterior margin; (PR) prosoma; (Al-IV) areas I-IV; (ST) spots. Asterisk ( ${ }^{*}$ ) indicate the diagnostic features of new species.

\begin{tabular}{|c|c|c|c|c|c|c|c|c|}
\hline Species & Spine on area III & $\begin{array}{l}\text { Granulation on } \\
\text { dorsum / spine }\end{array}$ & \multicolumn{3}{|c|}{ Dorsal / ventral armature on pedipalps } & $\begin{array}{l}\text { Shape of penial } \\
\text { distal margin }\end{array}$ & \multicolumn{2}{|c|}{$\begin{array}{c}\text { Number of penial } \\
\text { ventral plate basal } \\
\text { setae (group A) }\end{array}$} \\
\hline C. arietinus (Mello-Leitão, 1940) & single & present on both & \multicolumn{3}{|c|}{ one row of short basal TUB /one row of long TUB } & shallow concavity & two & \\
\hline C. biacutus Roewer, 1947 & geminate (distal half) & present on both & \multicolumn{3}{|c|}{ one row of short TUB / one row of TUB } & - & - & \\
\hline C. birramosus (González-Sponga, 1998) & geminate (distal half) & present on both & \multicolumn{3}{|c|}{ smooth / one row of short TUB } & truncated & two & \\
\hline C. columnaris (Roewer, 1927) & single & present on both & \multicolumn{3}{|l|}{-} & - & - & \\
\hline C. coxaepunctatus Roewer, 1927 & single & absent on both & \multicolumn{3}{|l|}{-} & - & - & \\
\hline C. flavopictus Simon, 1880 & single & present on both & \multicolumn{3}{|l|}{-} & - & - & \\
\hline C. mesacanthus Kollar in Koch, 1839 & geminate & only on dorsum & \multicolumn{3}{|l|}{-} & - & - & \\
\hline C. migdaliae (González-Sponga, 1992) & geminate (distal half) & present on both & \multicolumn{3}{|c|}{ short basal TUB / one row of long TUB } & - & one & \\
\hline C. peruvicus (Avram \& Soares, 1983) & geminate & present on both & \multicolumn{3}{|c|}{ short TUB / one row of long TUB } & deep U-cleft & one & \\
\hline C. pleurostigma Sorensen, 1932 & - & - & \multicolumn{3}{|l|}{-} & - & - & \\
\hline C. pulcher Goodnight \& Goodnight, 1942 & single & present on both & \multicolumn{3}{|c|}{ one row of TUB / one row of TUB } & - & - & \\
\hline C. serrulatus (González-Sponga, 1992) & geminate (distal half) & present on both & \multicolumn{3}{|c|}{ short basal TUB / one row of long TUB } & - & none & \\
\hline C. soerenseni (Mello-Leitão, 1942) & geminate & only on dorsum & \multicolumn{3}{|l|}{-} & - & - & \\
\hline C. turritus Sorensen, 1932 & - & - & \multicolumn{3}{|l|}{-} & - & - & \\
\hline C. unispinosus (Roewer, 1916) & geminate (distal half) & present on both & \multicolumn{3}{|l|}{-} & - & - & \\
\hline C. variolosus Mello-Leitão, 1942 & geminate (distal half) & present on both & \multicolumn{3}{|l|}{-} & straight & one & \\
\hline C. varius Perty, 1833 & geminate & absent on both & \multicolumn{3}{|l|}{ sparse TUB / one row of TUB } & - & - & \\
\hline C. pollera sp. nov. & geminate (distal half) & *absent on both & \multicolumn{3}{|c|}{ smooth / one row of long TUB } & *deep V-cleft & *three & \\
\hline C. balboa sp. nov. & single & present on both & \multicolumn{3}{|c|}{ basal TUB / one row of long TUB } & *shallow concavity & *two & \\
\hline C. burbayar sp. nov. & single & present on both & \multicolumn{3}{|c|}{ basal TUB / one row of long TUB } & *shallow concavity & *none & \\
\hline C. tamboritos sp. nov. & geminate (distal half) & present on both & \multicolumn{3}{|c|}{ basal TUB / *one row of long TUB on median region } & *straight & *none & \\
\hline Species & & Coloration of dorsal & scutum & Claws III-IV & $\begin{array}{l}\text { Shape of } \\
\text { spine apex } \\
\text { on area III }\end{array}$ & Surface of femur & & $\begin{array}{l}\text { Dimorphic } \\
\text { chelicerae }\end{array}$ \\
\hline C. arietinus (Mello-Leitão, 1940) & small rounded ST & & & smooth & pointed & smooth & & absent \\
\hline C. biacutus Roewer, 1947 & small rounded $\mathrm{ST}, \mathrm{tw}$ & o larger ST near Al & & smooth & pointed & smooth & & - \\
\hline C. birramosus (González-Sponga, 1998) & $\begin{array}{l}\text { irregular V-shape ST } \\
\text { on center of areas }\end{array}$ & between distal PR a & and $\mathrm{Al}$, small rounded ST & smooth & pointed & one row of short TUB & & present \\
\hline C. columnaris (Roewer, 1927) & uniformly colored of & brown & & smooth & blunt & smooth & & - \\
\hline C. coxaepunctatus Roewer, 1927 & irregular ST on LM an & d lateral sides of dor & rsal areas, small rounded ST & smooth & pointed & sSmooth & & - \\
\hline C. flavopictus Simon, 1880 & small rounded ST, na & Irow stripe on EM & of $\mathrm{AM}$ and $\mathrm{LM}$ & smooth & blunt & smooth & & absent \\
\hline C. mesacanthus Kollar in Koch, 1839 & pale with small dark & rounded ST & & smooth & pointed & smooth & & absent \\
\hline C. migdaliae (González-Sponga, 1992) & irregular and disconti & inuous ST from PR & to PM, small rounded ST & smooth & pointed & one row of short TUB & & present \\
\hline C. peruvicus (Avram \& Soares, 1983) & small rounded ST & & & pectinate & blunt & lateral long row of TUB & & absent \\
\hline C. pleurostigma Sorensen, 1932 & small rounded ST & & & - & - & - & & - \\
\hline C. pulcher Goodnight \& Goodnight, 1942 & narrow stripe on AM & and LM & & smooth & pointed & smooth & & absent \\
\hline C. serrulatus (González-Sponga, 1992) & irregular continuous $S$ & $S T$ from $P R$ to $P M p$ & osterior, small rounded ST & smooth & pointed & ventral row of short TL & UB & present \\
\hline C. soerenseni (Mello-Leitão, 1942) & - & & & smooth & pointed & smooth & & absent \\
\hline C. turritus Sorensen, 1932 & - & & & smooth & - & - & & - \\
\hline C. unispinosus (Roewer, 1916) & narrow stripe on LM & & & smooth & pointed & smooth & & - \\
\hline C. variolosus Mello-Leitão, 1942 & small rounded ST & & & smooth & pointed & smooth & & absent \\
\hline C. varius Perty, 1833 & $\begin{array}{l}\text { irregular ST, V-shapec } \\
\text { irregular ST on all LM }\end{array}$ & $\mathrm{d}$ between posterio & r region of $\mathrm{PR}$ and sulcus $\mathrm{I}$, & smooth & pointed & smooth & & absent \\
\hline C. pollera sp. nov. & $\begin{array}{l}\text { *two large ST on late } \\
\text { surface of PM (round } \\
\text { on AM }\end{array}$ & $\begin{array}{l}\text { ral surface of PR, tv } \\
\text { led, light colored a }\end{array}$ & $\begin{array}{l}\text { wo large ST on lateral } \\
\text { nd large), two smaller ST }\end{array}$ & smooth & pointed & $\begin{array}{l}\text { *dorsal and ventral sm } \\
\text { TUB }\end{array}$ & & present \\
\hline C. balboa sp. nov. & *uniformly colored & & & smooth & ${ }^{*}$ rombous & smooth & & absent \\
\hline C. burbayar sp. nov. & *irregular discontinuc & ous ST from PR to $P$ & & smooth & pointed & smooth & & present \\
\hline C. tamboritos sp. nov. & irregular ST along all & LM & & smooth & pointed & $\begin{array}{l}\text { prolateral and ventral r } \\
\text { of long TUB, *bifid } \\
\text { retrolateral apical TUB }\end{array}$ & rows & present \\
\hline
\end{tabular}



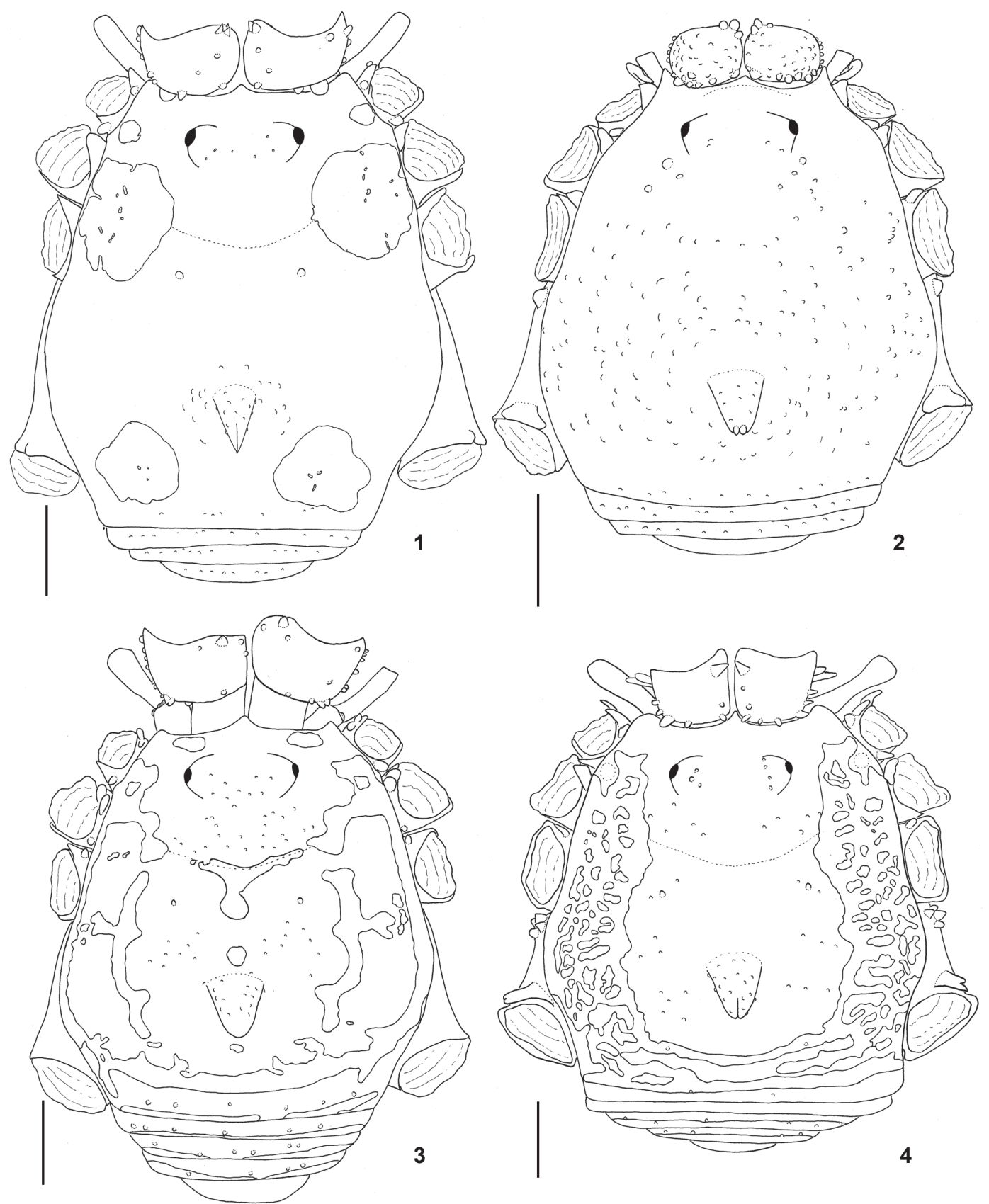

Figures 1-4. Habitus of males of Cosmetus in dorsal view: (1) Cosmetus pollera sp. nov. (MIUP); (2) Cosmetus balboa sp. nov. (MIUP); (3) Cosmetus burbayar sp. nov. (MIUP); (4) Cosmetus tamboritos sp. nov. (MIUP). Scale bars = $1 \mathrm{~mm}$.

ozopore. Prosoma smooth, ocularium with median depression, small-tuberculate. Area I with one pair of tubercles; area II smooth; area III with spine geminate and bifid on its apical third, apex rounded and directed backwards, base more tuberculated than apex. Posterior margin and free sternites with a row of small tubercles. Anal operculum with setae.
Venter. Coxa I with one row of 14 tubercles and 13 sparse tubercles. Coxa II, III and IV with sparse setiferous tubercles. Genital operculum and stigmatic area with few sparse small tubercles.

Chelicera. Dimorphic. Bulla with one large tubercle on proximal retrolateral region, eight small retrolateral tubercles, one tubercle on median region and two-three tubercles on prolateral 


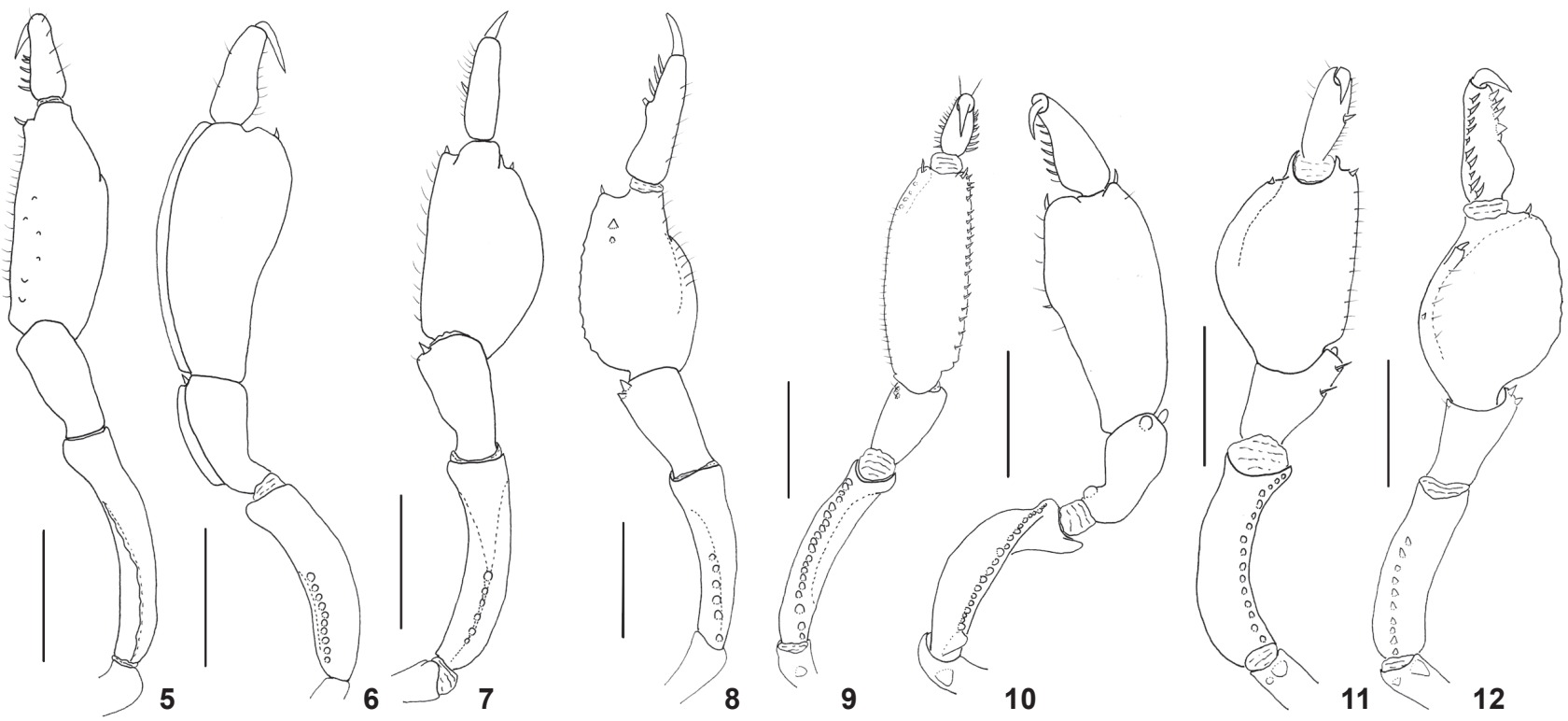

Figures 5-12. Right pedipalpus of males of Cosmetus. (5-8) dorsal view: (5) Cosmetus pollera sp. nov.; (6) Cosmetus balboa sp. nov.; (7) Cosmetus burbayar sp. nov.; (8) Cosmetus tamboritos sp. nov. (9-12) ventral view: (9) Cosmetus pollera sp. nov.; (10) Cosmetus balboa sp. nov.; (11) Cosmetus burbayar sp. nov.; (12) Cosmetus tamboritos sp. nov. Scale bars $=1 \mathrm{~mm}$.

apical region. Segment II with setae on distal region, fixed finger smooth. Segment III without tooth and with intracheliceral space.

Pedipalp (Figs. 5, 9). Trochanter elongated with one ventro-distal tubercle. Femur elongate, with one ventral row of 20 tubercles, with tubercles irregularly distributed dorsally. Patella with two small prolateral distal tubercles and several sparse setae. Tibia elongate, with one row of lateral setae that increase in width towards apex, with one distal tubercle and six prodorsal tubercles. Tarsus covered by thin setae, with one retrolateral row of thick setae and other prolateral row until apex (setae larger than retrolateral).

Legs. Coxa I with one dorsal tubercle and one tubercle on each side: one directed towards pedipalp and one directed towards coxa II, three prolateral tubercles. Coxa II with one tubercle directed towards coxa I. Coxa III smooth. Coxa IV with small tubercles irregularly distributed and one distal wide, short and blunt tubercle. Trochanter I with three ventral tubercles; II and III smooth; trochanter IV with two distal retrolateral tubercles. Femora I-IV small-tuberculated; I with slightly larger tubercles on proximal ventral region; II with one-two medianlateral tubercles; III with two dorsal rows of small tubercles, increasing in size towards apex. Patella IV with four distal retrolateral tubercles, one prolateral tubercle. Tibiae smooth. Tarsal segmentation: 7(3), 16(3), 12, 13.

Penis (MZSP 67283) (Figs. 13-15). Distal margin of ventral plate with strong V-cleft, corners divergent. Thin microsetae only on ventro-lateral margins, from base to apex, medianventral region smooth. Lateral margins convergent until sub- apical region; presence of two distal pairs of straight and cylindrical setae and one pair shorter than others setae (group C); one pair of median, straight and cylindrical (group B), and three pairs of cylindrical and straight basal setae from base to median region (group A). Glans elongated, dorsal process well developed. Stylus flattened dorso-ventrally and swollen at apex, serrate caruncle on apex, with small and sparse projections.

Coloration. Dorsal scutum dark brown with lighter margins. A pair of small yellow spots close to anterior margin, two large yellow spots on prosoma, from lateral margin to area I, two large yellow spots on area III, from posterior margin to near base of spine. Chelicera, pedipalp, legs and free tergites light brown.

Female (MZSP 67281 paratype). Measurements. Dorsal scutum: length: 3.9 , width: 3.85; Prosoma: length: 1.2 , width: 2.3; Interocular distance: 0.7; Chelicera: 2.0; Pedipalp: 5.0, femur: 1.3; Legs I: 17.3, II: 40.4, III: 23.1, IV: 32.0; Femur IV: 10.0.

Anterior margin narrow. Area I with one pair of small tubercles, area III with bifid spine, less tuberculate than male. Free tergites with few small tubercles sparsely distributed. Chelicera: bulla with three retrolateral tubercles, six proximal tubercles and three distal retrolateral tubercles. Pedipalpal patella with one distal prolateral tubercle, tibia with small lateral spines. Coxa I with one tubercle directed towards pedipalp and one small tubercle directed towards coxa II. Trochanter I with two ventral tubercles. Femora small tuberculated. Patella IV smooth.

Material examined. Male holotype from Panama, Provincia Panama ("Reserva Natural Privada Burbayar" $\left.9^{\circ} 19^{\prime} 57^{\prime \prime} \mathrm{N}, 78^{\circ} 59^{\prime} 15^{\prime \prime} \mathrm{W}\right), 20 . \mathrm{I} .2013$, R. Pinto-da-Rocha \& A. 
Santos leg. (MIUP). Paratypes, same data as holotype: 4 females and 1 male (MIUP); 1 female (MZSP 67281); 2 males and 6 females (MZSP 67282), 1 male (MZSP 67283).

Distribution. Known only from the type locality.

Etymology. The specific name "pollera" (noun in apposition) was taken from the Panamanian culture and refers to a typical dress and symbol of Panamanian pride. The dress is used during festivals or celebrations, is multicolored and is made from cotton and wool.

\section{Cosmetus balboa sp. nov.}

Figs. 2, 6, 10, 16-18, 32

Diagnosis. Cosmetus balboa sp. nov. (Figs. 2, 10) is similar to C. columnaris (ROEWER 1927) in having a high, tuberculate and blunt spine on area III and dorsal scutum without spots (see Roewer 1927: 627, fig. 50). It is also similar to $C$. biacutus Roewer, 1947 in having two tubercles on the apex of the spine on area III and one proximal dorsal tubercle on coxa IV (see Roewer 1947: 31, fig. 102). C. balboa sp. nov. can be distinguished by its smooth ocularium (ocularium with tubercles in C. columnaris, see ROEWER 1927), larger distal tubercle on pedipalpal femur (tubercles of same size in C. columnaris and $C$. biacutus), coxa I with large ventral tubercle directed upwards (C. columnaris and C. biacutus without ventral tubercle directed upwards, see Roewer 1927 and Roewer 1947: 31, pl. 12, fig. 102 respectively), coxa IV with one large dorsoproximal tubercle (C. columnaris possesses three dorsoproximal tubercles), two geminate (from base) dorsoapical tubercles with blunt apex (C. columnaris possess two apical tubercles not geminate, see Roewer 1927: 627, fig. 50 and C. biacutus have one distal apophysis, see Roewer 1947: 31, pl. 12, fig. 102).

Description. Male (holotype). Measurements. Dorsal scutum: length: 3.65 , width: 3.45 ; Prosoma: length: 1.45 , width: 2.5; Interocular distance: 0.9; Chelicera: 1.75 ; Pedipalp: 4.5 , femur: 1.3; Legs I: 18.45, II: 46.5, III: 25.0, IV: 36.2; Femur IV: 12.2 .

Dorsum (Figs. 2, 32). Body shape type beta (KunY et al. 2007). Anterior margin smooth, with two elongated paracheliceral projections. Lateral margin with small sparse tubercles, ozopore with lateral projection. Prosoma with one pair of small tubercles behind ocularium and small tubercles irregularly distributed. Ocularium with sparse small tubercles. Areas not well delimited, tuberculate. Area III with long and tuberculated spine, apex with two large tubercles, base wide, from sulcus III to sulcus IV. Posterior margin and free tergites with one row of small tubercles. Anal operculum small tuberculate, with setae.

Venter. Coxa I with two rows of wide tubercles, one row near to coxa II with 9-11 tubercles, other row near pedipalpal coxa with four tubercles, short tubercles on posterior region, one distal tubercle directed towards coxa II. Coxa II with small tubercles, two small tubercles directed towards coxa I, four tubercles united to coxa III. Coxa III with five-seven tubercles united to coxa IV. Genital operculum with setiferous small tubercles, stigmatic area smooth.
Chelicera. Bulla covered by small tubercles, with four larger basal retrolateral tubercles, one prolateral basal tubercle, three prolateral apical tubercles. Segment II with three small teeth on fixed finger. Segment III with one basal tooth, with intracheliceral space.

Pedipalp (Figs 6, 10). Trocanter with one ventro-distal tubercle. Femur compressed, with one row of 10 dorsal tubercles, one ventral row of 21 tubercles and one distal tubercle. Patella with one distal prolateral tubercle and one ventral tubercle. Tibia elongate, with two lateral distal spines. Tarsus with setae on prolateral and retrolateral regions.

Legs. Coxa I with one dorsal tubercle on each side, one directed towards pedipalp, other towards coxa II; ventral tubercle directed upwards, its apex almost reaching the tubercle near pedipalp, one retrolateral apical tubercle. Coxa II with one tubercle directed towards coxa I, one prolateral tubercle. Coxa III with one dorsal tubercle near coxa II. Coxa IV with one dorsal proximal and two tubercles with blunt apex united since their base on dorsal distal region. Trochanters I-IV tuberculate. Femora I-III with one basal tubercle, IV with one ventro-distal tubercle. Patellae I, II, III and IV with two dorsal distal tubercles. Tibiae smooth. Tarsal segmentation: 7(3), 16 (3), 13, 15.

Penis (MZSP OP 1565) (Figs. 16-18). Ventral plate wide and subretangular, wider at apical region, lateral margins straight, distal corners rounded, distal margin concave. Densely covered with thin microsetae on lateral margin, from median to apical region. Two pairs of small setae on basal region (group A); two pairs of large and curved distal setae and one pair of cylindrical setae with pointed apex (only distally tapering) on the median lateral margin (group C); one pair of basal ventral short setae (group E). Glans elongate, dorsal process well developed. Serrate caruncle of stylus with long ventral projections almost until apex.

Coloration. Light yellow, free tergites, legs and distal half of area III spine darker. Patellae and apex of tibiae lighter.

Female unknown.

Material examined. Male holotype from Panama, Provincia Panama ("Reserva Natural Privada Burbayar" 09¹9'57"N, 7859'15”W), 20.I.2013, R. Pinto-da-Rocha \& A. Santos leg. (MIUP). Paratype, same data as holotype: 1 male, (MZSP 68120).

Distribution. Known only from the type locality.

Etymology. The specific name "balboa" (in apposition) is a patronym in honour of Vasco Nuñez de Balboa, the first European to explore Panama. It is also the name of the Panamanian currency, first coined in the 1940's.

\section{Cosmetus burbayar sp. nov.}

Figs. 3, 7, 11, 19-21, 33

Diagnosis. Cosmetus burbayar sp. nov. is similar to $C$. birramosus (González-Sponga, 1998), C. migdaliae (GonzálezSponga, 1992) and C. serrulatus (González-Sponga, 1992) by the irregular spot on dorsal scutum (Figs. 3, 33), additionally 

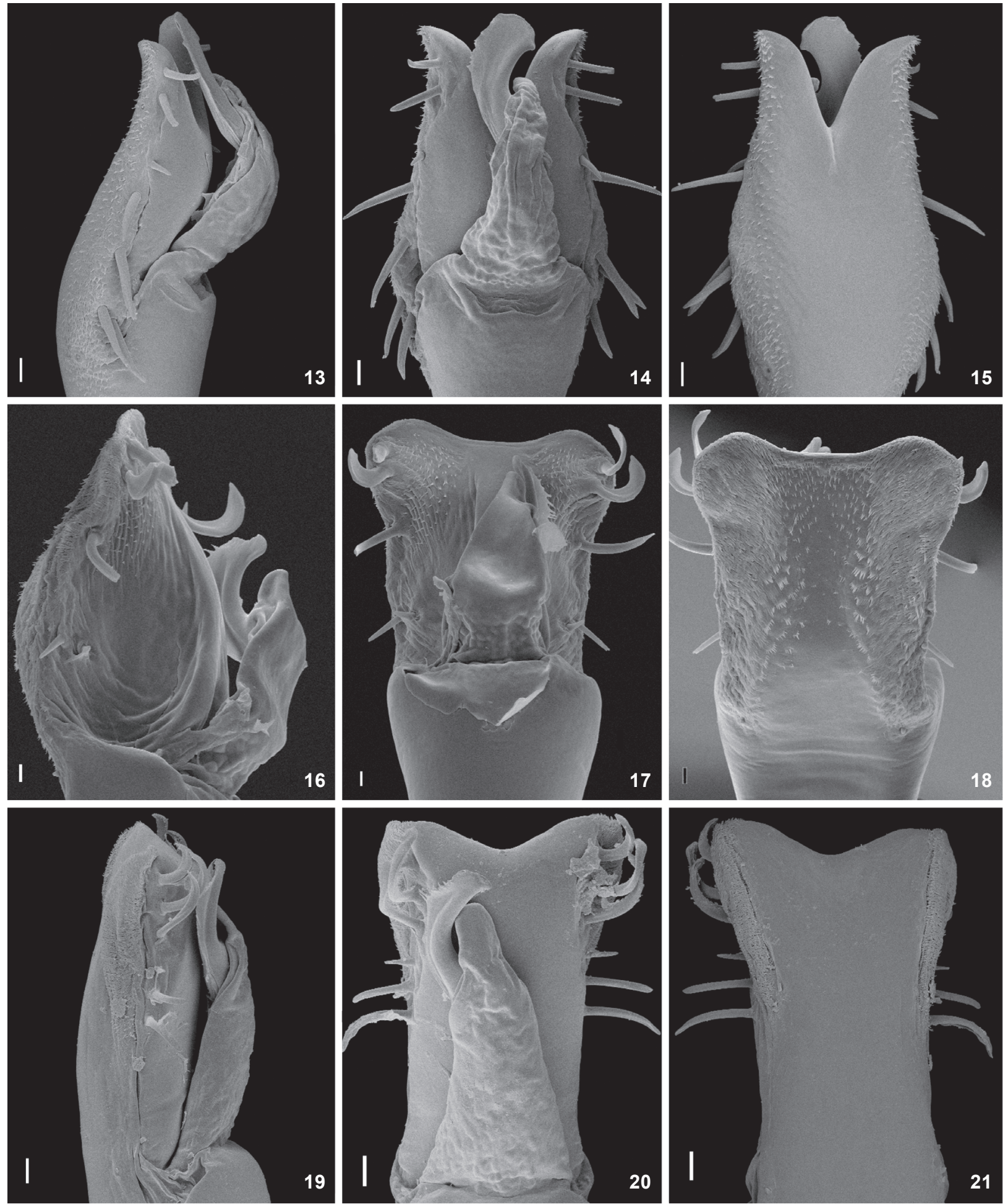

Figures 13-21. Penis of Cosmetus. (13-15) Cosmetus pollera sp. nov. (MZSP 67283): (13) Lateral view; (14) dorsal view; (15) ventral view. (16-18) Cosmetus balboa sp. nov. (MZSP OP 1565): (16) lateral view; (17) dorsal view; (18) ventral view. (19-21) Cosmetus burbayar sp. nov. (MZSP 67286): (19) lateral view; (20) dorsal view; (21) ventral view. Scale bars: $(13-15 ; 19-21)=20 \mu \mathrm{m}:(16-18)=10 \mu \mathrm{m}$. 
shares with C. serrulatus the bifid tubercle on coxa II (Fig. 3). Cosmetus burbayar sp. nov. can be distinguished from other species of the genus by the irregular and discontinuous shape of its yellow spot, extending from lateral anterior to posterior margins and invading prosoma, areas I-III and free tergites (Figs. 3, 33; C. birramosus possesses an irregular spot only on prosoma and area I, see GonzÁlez-Sponga 1998: 3, fig. 8; C. migdaliae possesses irregular spot from behind ocularium to areas I and II, and irregular spot from posterior margin to area III, see GonZÁLEz-SPONGA 1992: 186, fig. 220; C. serrulatus possesses irregular spot continuous from leg II to posterior margin, see GonzÁlez-Sponga 1992: 190, fig. 226); coxa I with one bifid prolateral tubercle (absent in C. birramosus, $C$. migdaliae and C. serrulatus) (Fig. 3); cheliceral segment II with large basal tooth on fixed finger (absent in C. birramosus, while C. migdaliae and C. serrulatus possess a small basal tooth, see GonZÁlez-Sponga 1992: 186, fig. 222 and GonZÁlez-SpONGA 1992: 190, fig. 228).

Description. Male (holotype). Measurements. Dorsal scutum: length: 4.1, width: 4.25; Prosoma: length: 1.3 , width: 3.25; Interocular distance: 1.25; Chelicera: 3.25; Pedipalp: 6.25, femur: 1.9; Legs I: 18.9, II: 45.0, III: 25.0, IV: 35.8; Femur IV: 11.0.

Dorsum (Figs. 3, 33). Body shape type Beta (KunY et al. 2007). Anterior margin smooth, with two short paracheliceral projections. Lateral margin slightly projected near ozopore. Prosoma smooth, ocularium with small tubercles. Ocularium with moderate median depression. Area I with one small tubercle, sulcus I visible; area II with sparse small tubercles; area III with central elongated single spine with rounded apex and covered with small tubercles. Posterior margin and free tergites with small setiferous tubercles in one row (tergites I and II with 14 , III with 11 small tubercles). Anal operculum with irregularly distributed setae.

Venter. Coxa I with anterior row of 10 large tubercles and several small, sparsely distributed. Coxae II, III and IV densely covered by sparse tubercles. Genital operculum with small tubercles, stigmatic area smooth.

Chelicera. Dimorphic. Bulla with one-two distal tubercles, four retrolateral tubercles, two tubercles on proximal dorsal region, three proximal prolateral tubercles. Tuberculate dorsally. Segment II with setae on distal region, with one basal tooth on fixed finger. Segment III with one basal tooth, with intracheliceral space.

Pedipalp (Figs. 7, 11). Trochanter with two ventro-distal tubercles. Femur compressed, with one dorsal row of six tubercles, one ventral row of 16 tubercles. Patella with one distal retrolateral tubercle, two retrolateral distal ventral setae. Tibia with retrolateral margin depressed, with setae on lateral margin directed downwards, two wide setae on distal region. Tarsus with lateral margin covered with short setae, one ventral retrolateral setae larger.

Legs. Coxa I with one bifid prolateral and one single retrolateral tubercles. Coxa II with one bifid tubercle directed towards coxa I, one single tubercle directed towards coxa III. Coxa III with one tubercle directed towards coxa II. Coxa IV with one wide distal elevation. Trochanters I-IV with ventral tubercles, trochanter III with one distal prolateral tubercle, IV with one distal retrolateral tubercle. Femora smooth. Patella IV with one distal prolateral and one retrolateral projections. Tarsal segmentation: 12(3), 21(3), 16, 18.

Penis (MZSP 67286) (Figs. 19-21). Ventral plate with shallow concavity on distal margin, lateral margins parallel on basal $2 / 3$, apical $1 / 3$ slightly wider. Ventro-median to distal margin with small triangle-like projection. Three pairs of curved and flattened dorso-distal setae (group C); three pairs of cylindrical setae on median region, distal most pair smaller than others (group D), without setae on basal region. Glans elongated, dorsal process well developed. Stylus swollen apically, serrate caruncle with short ventral projections until subapical region.

Coloration. Brown orange, reticulate with dark brown on dorsum, chelicerae and legs. Two large yellow and rounded spots on posterior margin. Yellow stripe on lateral margin from coxa I to posterior margin, projecting to prosoma near leg I. Yellow spot on anterior to center of area I and surrounding areas I, II and III. One yellow spot anterior to spine of area III, one behind it. One yellow spot from margin of area II to lateral margin.

Female (MZSP 67285 paratype). Measurements. Dorsal scutum: length: 4.55 , width: 4.35; Prosoma: length: 1.25 , width: 2.55; Interocular distance: 0.95; Chelicera: 2.25; Pedipalp: 5.0, femur: 1.25; Legs I: 19.05, II: 45.1, III: 24.75, IV: 36.2; Femur IV: 11.25 .

Dorsal scutum wider than male. Anterior margin narrower than male. Area II and posterior margin smooth. Free tergites with few small tubercles. Coxa I with one ventral row of 13 tubercles and some sparse tubercles. Chelicera similar to male, bulla with three prolateral tubercles, five retrolateral tubercles, two-three dorso-distal tubercles, 12 small teeth on movable finger. Pedipalp femur with one ventral row of 21 small tubercles. Coxa II with anterior tubercle directed towards coxa I, coxa III smooth, coxa IV with small dorsal elevation, patella IV smooth. Tarsal segmentation: 9(3), 20(3), 15, 18. Female coloration differs from male in having only two yellow spots on anterior margin, with yellow narrow stripe surrounding the dorsal scutum external margin, beginning on anterior margin and entering in the prosoma. Two patches on prosoma anterior to area I. Small patches surrounding area II, three patches on central of area, near spine, one patch behind each spine.

Material examined. Male holotype from Panama, Provincia Panama ("Reserva Natural Privada Burbayar" 09¹9'57”N, 7859'15”W), 20.I.2013, R. Pinto-da-Rocha \& A. Santos leg. (MIUP). Paratypes, same data as holotype: 3 females (MIUP); 1 male 3 females (MZSP 67284); 1 female (MZSP 67285); 1 male (MZSP 67286).

Distribution. Known only from the type locality. 

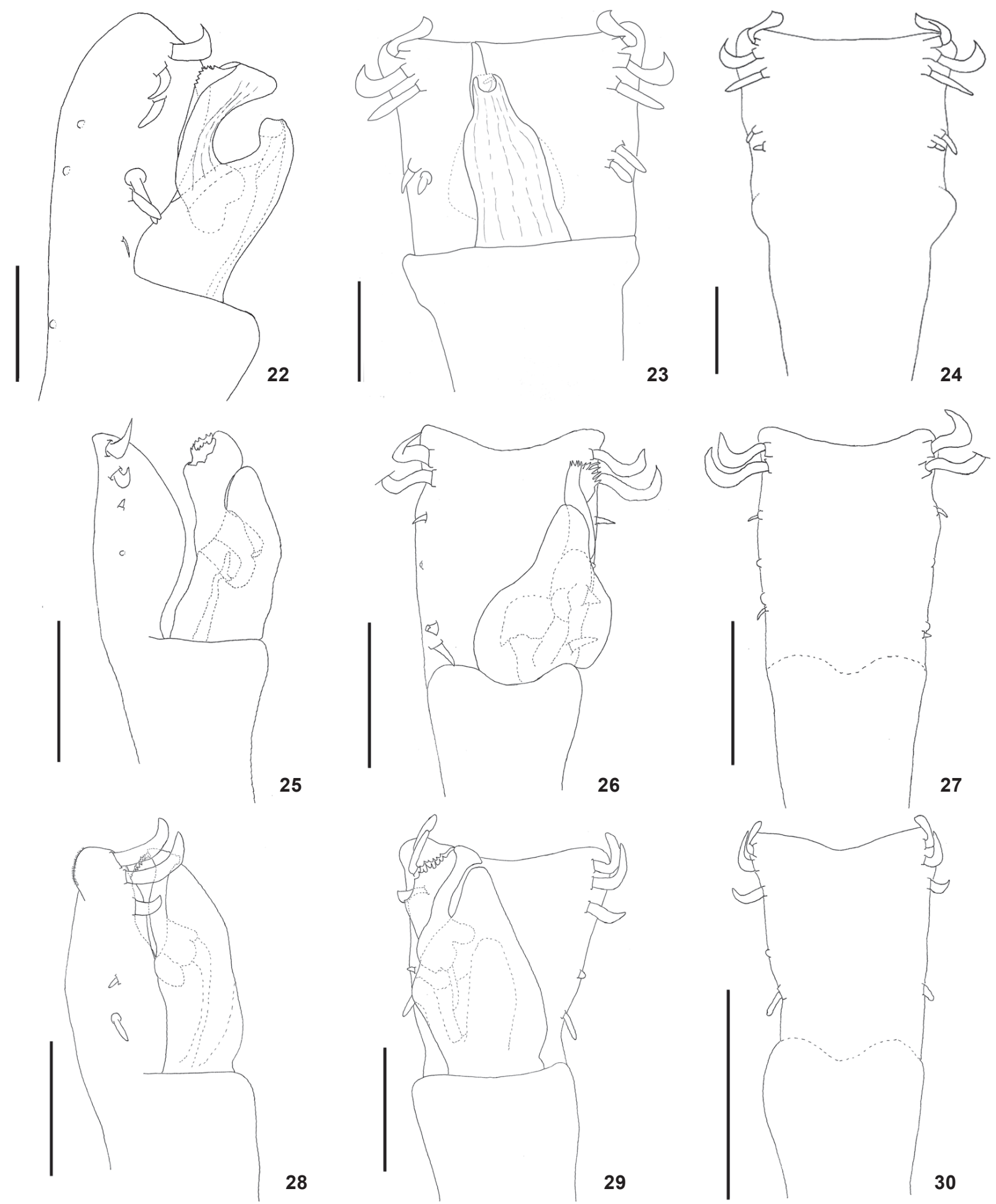

Figures 22-30. Penis of Cosmetus. (22-24) Cosmetus tamboritos sp. nov. (MIUP): (22) lateral view; (23) dorsal view; (24) ventral view. (25-27) Cosmetus arietinus (MZSP 14038): (25) lateral view; (26) dorsal view; (27) ventral view. (28-30) Cosmetus variolosus (MZSP 238): (28) lateral view; (29) dorsal view; (30) ventral view. Scale bars $=1 \mathrm{~mm}$. 
Etymology. The specific name is a noun in apposition and refers to the type locality of this species, an astonishing private reserve in Burbayar. The name is taken from the Kuna language (spoken in southwestern Panama and northwestern Colombia) and means "spirit of the mountains".

\section{Cosmetus tamboritos sp. nov.}

Figs. 4, 8, 12, 22-24, 34

Diagnosis. Cosmetus tamboritos sp. nov. (Figs. 4, 34) is similar to C. coxaepunctatus Roewer, 1927 and C. unispinosus (Roewer, 1916) by the descontinuous patch along all extension of lateral margin of dorsal scutum, although in $C$. coxaepunctatus the patch is V-shaped when surrounding the margin of all areas (see Roewer 1927: 609, fig. 40), in $C$. unispinosus the patch is restricted to lateral margin of dorsal scutum, and does not reach areas or posterior margin of opisthosoma (see RoEwer 1916: 394, fig. 486). Cosmetus tamboritos sp. nov. is distinguished by having two retrolateral apical tubercles on bulla, one being double size of other (absent in C. coxaepunctatus and C. unispinosus); coxa IV lacks patches of a cluster of four tubercles on dorsolateral proximal region and two pointed tubercles fused at their apices $(C$. coxaepunctatus possesses five yellow patches, one dorsal apical tubercle on coxa IV, see Roewer 1927: 609, fig. 40; C. unispinosus has one patch and one apical tubercle on coxa IV, see RoEwer 1916: 394, fig. 486); femur IV with bifid retrolateral apical tubercle (C. coxaepunctatus and C. unispinosus have a smooth femur IV, see Roewer 1927 and Mello-LeITÃo 1932, respectively).

Description. Male (holotype). Measurements. Dorsal scutum: length: 5.8, width: 5.3; Prosoma: length: 2.12, width: 4.3; Interocular distance: 1.3; Chelicera: 5.9; Pedipalp: 7.8, femur: 2.18; Legs I: 24.5, II: 53.0, III: 33.7, IV: 44.8; Femur IV: 13.2.

Dorsum (Figs. 4, 34). Body outline type Beta (KuRY et al. 2007). Anterior margin smooth, two lateral paracheliceral projections short and rounded. Lateral margin with small projection on the lateral surface of the ozopore. Prosoma with 10 small tubercles behind ocularium. Ocularium with shallow median depression, with seven small tubercles. Area I divided, with one pair of larger tubercles, two pairs of small tubercles on external side; II with six small tubercles; III with eight small tubercles, one single large spine at base, bifid on distal half, covered by tubercles. Posterior margin with one pair of central tubercles. Free tergites with one row of small tubercles. Anal operculum with several sparse small tubercles.

Venter. Region between coxae II-III ahead of genital operculum strongly depressed. Coxa I with one anterior row of 12 large tubercles, 15 posterior sparse, four on apical region. Coxae II-IV densely covered by sparse tubercles. Genital operculum with six small tubercles. Posterior margin and free sternites with one row of small tubercles. Stigmatic area with small setiferous sparse tubercles.

Chelicera. Dimorphic. Bulla with three proximal prolateral tubercles, one proximal retrolateral tubercle, two retrolateral apical tubercles of different sizes, two large distal prolateral tubercles. Segment II with setae on distal region, fixed finger smooth. Segment III with one basal tooth, one median tooth enlarged, eight small distal teeth, with intracheliceral space.

Pedipalp (Figs. 8, 12). Trochanter elongate, with two ventro-distal tubercles (proventral larger than retroventral). Femur compressed, with one row of 10-11 ventral tubercles on anterior third, one row of six dorsal tubercles on anterior half. Patella with two distal prolateral tubercles, one small setiferous retrodistal ventral tubercle. Tibia with prolateral and retrolateral margins compressed, with two distal lateral spines, small spines on lateral margins, two dorsal subapical tubercles. Tarsus with four prolateral wide setae (the basal much larger than other), 10 retrolateral wide setae, thin setae sparse.

Legs. Coxa I with two anterior tubercles fused at their base, one posterior tubercle directed towards coxa II. Coxa II with one anterior tubercle directed towards coxa I. Coxa III small apophysis directed towards coxa II. Coxa IV with a cluster of four well developed tubercles on dorsolateral proximal region, two pointed tubercles contiguous at their apices. Trochanter I with one enlarged retrolateral tubercle directed towards leg II, one distal retrolateral tubercle and four ventral tubercles; II with two prolateral basal tubercles directed towards leg I, one large retrolateral basal tubercle directed towards leg III, one tubercle on each lateral distal sideand four ventral tubercles; III with one enlarged tubercle on each lateral basal side, two smaller tubercles on each lateral distal surface, nine-ten ventral tubercles; IV with one enlarged tubercle on each basal lateral, two tubercles fused at their base on each lateral distal, nine ventral tubercles. Femora I and II with one row of dorsal small tubercles, one row of lateral small tubercles and two ventral rows of small tubercles; III with two dorsal rows of small tubercles, two ventral rows of large tubercles increasing in size to apex, proventral row of tubercles higher than the retroventral one; IV with two dorsal rows, one prolateral row of higher tubercles on anterior $1 / 4$, rows of tubercles increasing in size to apex, proventral row with higher tubercles than the retroventral one, with one apical retrolateral bifid tubercle. Patellae I and II smooth; III with small sparse tubercles; IV with two dorsal rows of eigth tubercles each (retrodorsal larger), one apical prodorsal tubercle longer than other of the segment, two retrodorsal longer than other of the same row. Tibia IV with two ventral rows of small tubercles, increasing in size to apex, retroventral apical larger than other, with distal apophysis. Basitarsus I swollen. Tarsal segmentation 7(3), 20(3), 11, 14.

Penis (MIUP) (Figs. 22-24). Ventral plate quadrangular, lateral margins parallel and straight, distal margin straight; three pairs of distal long setae (group C), two distal most pairs falciform, two intermediary pairs of straight setae and shorter (half the length of the distal setae) (group D), two rounded areas on ventral region. Truncus with one ventral short setae (group E). Glans elongate and thin. Serrate caruncle of stylus with short projection from ventral region to almost apex. 

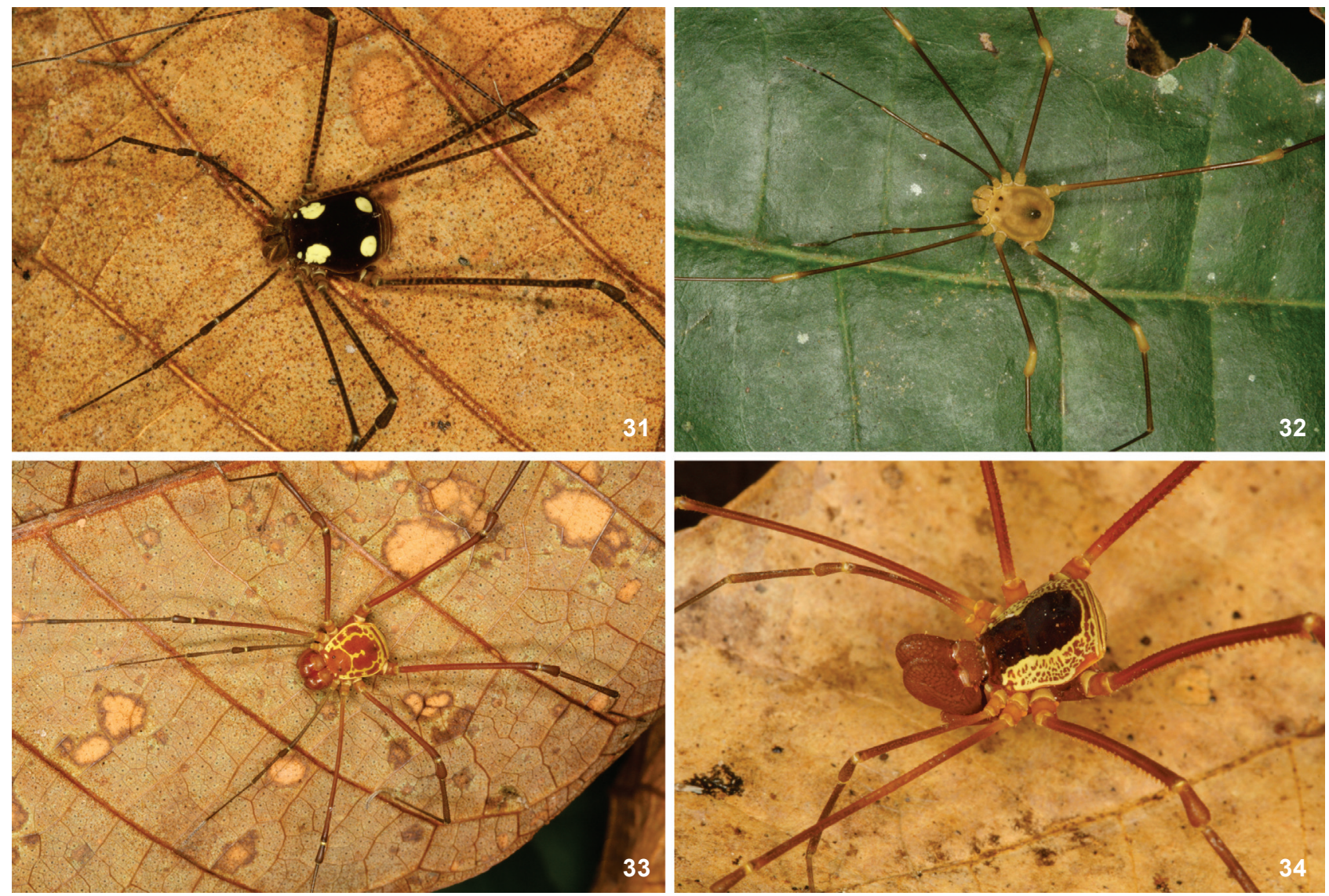

Figures 31-34. Habitus of males of Cosmetus on the field. (31) Cosmetus pollera sp. nov.; (32) Cosmetus balboa sp. nov.; (33) Cosmetus burbayar sp. nov.; (34) Cosmetus tamboritos sp. nov. Photos by RPR.

Coloration. Dorsal scutum and coxae dark brown. Chelicera brown. Legs and pedipalps light yellowish brown. Yellow patch U-shaped covering irregularly anterior margin, lateral surface of prosoma and areas, reaching the posterior margin and forming a narrow stripe behind spine. Dorsal scutum dark brown with small irregular yellow patches. Free tergites I-III with one stripe each.

Female (MZSP 67288 paratype). Measurements. Dorsal scutum: length: 5.4, width: 5.35; Prosoma: length: 1.85, width: 3.9; Interocular distance: 1.25; Chelicera: 3.2; Pedipalp: 7.75, femur: 2.25; Legs I: 10.0, II: 51.0, III: 32.75, IV: 43.6; Femur IV: 13.43.

Anterior margin narrower than male. Ocularium with nine small tubercles near eyes. Area II with nine small tubercles. Genital operculum with nine small tubercles. Bulla densely tuberculate dorsally, three-four tubercles on lateral surface of distal prolateral large tubercle, two proximal central dorsal tubercles, retrolateral tubercles smaller than male; apical retrolateral and prolateral tubercles well developed, movable finger with small teeth. Pedipalpal femur with one row of 10-
11 ventral tubercles, dorso-proximal row with four tubercles. Pedipalpal tibia with four small prolateral distal tubercles. Trochanter II with seven ventral tubercles. Femora III-IV with short tubercles, except on apical region of femur IV, with ventral tubercles slightly longer than the others. Patella IV with two dorsal rows of tubercles, three distal prolateral tubercles, several small tubercles on ventral region. Tibia IV small-tuberculate. Basitarsus I with similar diameter as distitarsus. Tarsal segmentation: 7(3), 19-20(3), 11, 12.

Material examined. Male holotype from Panama, Provincia Panama "Reserva Natural Privada Burbayar" $9^{\circ} 19^{\prime} 57^{\prime \prime}$ N, 7859'15”W). 20.I.2013, R. Pinto-da-Rocha \& A. Santos leg. (MIUP). Paratypes, same data as holotype: 2 females (MIUP); 3 females (MZSP 67287); 1 female (MZSP 67288).

Distribution. Known only from the type locality.

Etymology. The specific name "tamboritos" is a noun in apposition taken from the popular culture of Panama that refers to a drum style of music and a typical dance. Tamborito is danced by men and women from the central provinces of the country, dressed with colorful clothes. 


\section{Description of the penis of two additional Cosmetus species}

Cosmetus arietinus (Mello-Leitão, 1940) (MZSP 14038) (Figs. 25-27). Ventral plate elongate, distal margin concave, two apical pairs of long and curved setae and one pair median apical of short setae (group C). Two basal pairs of setae (group A). One pair ventral basal of short setae (group E). Truncus narrow and with the same diameter throughout almost all its extension. Glans elongated, with dorsal process. Serrate caruncle of stylus with short projections on apical region.

Cosmetus variolosus Mello-Leitão, 1942 (MZSP 238) (Figs. 28-30). Ventral plate elongate, distal margin slightly concave, two groups of lateral setae, one basal pair (group A) and one median pair of short setae (group D) (basal most twice as long as median pair), three pairs of apical long and curved setae (group C) (basal most smaller than others). Truncus elongated and with same diameter throughout almost all its extension. Glans elongated, with dorsal process almost as high as stylus. Serrate caruncle of stylus with elongated projections from median region to apex.

\section{DISCUSSION}

Among Laniatores, Cosmetidae has an impressive number of species, being almost as rich as Gonyleptidae, the richest family in this suborder. However, it has received much less attention than gonyleptids (see references in PINTO-DA-RochA et al. 2014). The limited interest on cosmetids is likely due to the absence of modern opiliologists in regions where the group is most diverse (Amazonian and Andean regions, and Central America), and the fact that researchers that work on other Neotropical groups are not very interested on cosmetids. An exception is the impressive work of GonZalez-Sponga (1992), who described and redescribed 92 cosmetid species from Venezuela. Thus, it was not a surprise to find four new species of Cosmetus in the northern part of its distribution, on ChocóDarién moist forest ecoregion (WWF 2015). That region also harbors the species C. flavopictus Simon, 1880. Northern to Chocó-Darién is the Isthmian-Atlantic moist forests ecoregion, where the northernmost record of the genus, the Panamanian species C. pulcher (see KunY 2003 for a general view on distribution of the genus), is found.

Recently, cosmetids have received somewhat increasing attention and new sets of characters have been proposed to enhance its generic classification, such as: the shape of the dorsal scutum (KuRY et al. 2007), shape of ocularium and tibia of pedipalp (Ferreira \& Kury 2010, Pinto-da-Rocha \& Hara 2011, Kury \& Barros 2014) and morphology of penis (Townsend et al. 2010, Ferreira \& Kury 2010, Pinto-Da-Rocha \& Hara 2011, Kury \& Barros 2014), and ovipositor (Walker \& Townsend 2014). However, a hypothesis on the morphological evolution of the groups is still lacking.

The morphology of the spine on area III of the male was the main character used by KuRy (2003) to place several similar cosmetids in Cosmetus. However, this feature is variable, and two species-groups can be recognized based on it: a single spine is observed in C. arietinus (Mello-Leitão, 1940), C. columnaris (Roewer, 1927), C. coxaepunctatus Roewer, 1927, C. pulcher Goodnight \& Goodnight, 1942, C. burbayar sp. nov. and C. balboa sp. nov., whereas a geminated spine is observed in $C$. biacutus Roewer, 1947, C. birramosus (González-Sponga, 1998), C. mesacanthus Kollar in Koch, 1839, C. migdaliae (GonzálezSponga, 1992), C. peruvicus (Avram \& Soares, 1983), C. serrulatus (González-Sponga, 1992), C. unispinosus (Roewer, 1916), C. variolosus Mello-Leitão, 1942, C. varius Perty, 1833, C. pollera sp. nov. and C. tamboritos sp. nov. The distribution of thin, short bristles on the venter of the ventral plate of the penis also seems to be an informative character It should be noted that the Caribbean genus Arucillus Silhavy, 1971 exhibits a similar armature.The armature of Arucillus, however, has very wide base, distal half bifid (contiguous or divergent in males, divergent in females see GonzÁlez \& Vasconcelos 2003) and dorsal scutum type alfa (gama in Cosmetus).

The species exhibiting sexual dimorphism in the size of the chelicerae also have noticeable ornamentation on male femur IV, which varies from granulation (C. pollera sp. nov.) to rows of lateral and ventral large tubercles (C. birramosus, $C$. migdaliae, C. peruvicus, C. serrulatus, and C. tamboritos sp. nov.). It should be noted that some species are known only from females (C. biacutus, C. columnaris, C. coxaepunctatus, and C. unispinosus) and sexual features are unknown. The ornamentation on femur IV seems to be a good source of diagnostic characters.

The penis of less than half of the species is known $(C$. arietinus, C. birramosus, C. migdaliae, C. peruvicus, C. serrulatus, C. variolosus, C. pollera sp. nov., C. balboa sp. nov., C. burbayar sp. nov., C. tamboritos sp. nov.). There are differences in the shape of the distal margin of the penis (straight or concave) and the number of setae in the basal groups of the penial ventral plate.

The structure of the spine of area III, sexual dimorphism of chelicerae and armature of posterior legs, and pigmentation of dorsal scutum (see Table 1) are good diagnostic features at the species level. However, at present, without a phylogenetic hypothesis, it is difficult to recognize species clades within Cosmetus, or even to know if the genus is monophyletic.

\section{ACKNOWLEDGMENTS}

This study was supported by CNPq grants (ACR and RPR). We acknowledge A. Santos (Universidad de Panama) for his help during field work, Diomedes Quintero Arias (MIUP) for facilities during the visit of RPR to MIUP, Jimmy J. Cabra for revision and suggestions on the manuscript and Cristina A. Rheims for English revision. Financial support FAPESP (\#2012/ 029969-6). 


\section{LITERATURE CITED}

Avram S, Soares HEM (1983) Opilionides de Perou et d'Argentine, p. 47-64. In: Avram S, Soares HEM (Eds). Resultats des Expéditions biospéologiques cubano-roumaines a Cuba. Bucuresti, Editura Academiei Republicii Socialiste România, vol. 4.

DaSilva MB, Gnaspini P (2009) A systematic revision of Goniosomatinae (Arachnida: Opiliones: Gonyleptidae), with a cladistic analysis and biogeographical notes. Invertebrate Systematics 23: 530-624.

Ferreira CP, Kury AB (2010) A review of Roquettea, with description of three new Brazilian species and notes on Gryne (Opiliones, Cosmetidae, Discosomaticinae). Zoological Science 27: 697-708. doi: 10.2108/zsj.27.697

Gervals P (1842) Arachnides. Description et figures de quatre espèces nouvelles de Phalangiens. Magasin de Zoológie, Série 2, 4: 1-5.

Gervais P (1844) Acères Phrynéides, Scorpionides, Solpugides, Phalangides et Acarides; Dicères Épizoïques, Aphaniptères et Thysanoures, p. 94-131. In: WalCKenaer CA (Org.) Histoire naturelle des Insectes Aptères, 3. Paris, Librairie Encyclopédique de Roret.

GonZÁlez-Sponga MA (1992) Aracnidos de Venezuela. Opiliones Laniatores II. Familia Cosmetidae. Caracas, Academia de Ciencias Fisicas, Matemáticas y Naturales, 432p.

GonzÁlez-Sponga MA (1998) Aracnidos de Venezuela. Un nuevo género y cinco nuevas especies de Opiliones Laniatores (Cosmetidae). Acta Biologica Venezuelica 18(4): 1-16.

GonzÁlez AP, Vasconcelos E (2003) A new species of Arucillus Silhavy, 1971 from the Dominican Republic (Opiliones: Laniatores: Cosmetidae). Revista Ibérica de Aracnologia 7: 135-140.

Goodnight JC, Goodnight ML (1942) Phalangids from Central America and the West Indies. American Museum Novitates 1184: 1-23.

Goodnight JC, Goodnight ML (1953) The opilionid fauna of Chiapas, Mexico, and adjacent areas. American Museum Novitates 1610: 1-8.

Косн CL (1839) Übersicht des Arachnidensystems. Nürnberg, Zweites Heft. C.H. Zeh, 38p.

Kuny, AB (2003) Annotated catalogue on the Laniatores of the New Word (Arachnida, Opiliones). Revista Ibérica de Aracnologia 1: 5-337.

Kuny AB (2009) Family Cosmetidae. In: Kury AB (Ed.) Project Opilionomicon. Rio de Janeiro, Museu Nacional, UFRJ. Available online at: http://www.museunacional.ufrj.br/mndi/ Aracnologia/Opilionomicon/Family\%20Cosmetidae.htm [Accessed: 11/02/2015]

KuRY AB (2011) Order Opiliones Sundevall, 1833. In: Zhang ZQ (Ed.) Animal biodiversity: An outline of higher-level classification and survey of taxonomic richness. Zootaxa 3148: 112-114.
KunY AB (2013) Order Opiliones Sundevall, 1833. In: ZHAng ZQ (Ed.) Animal biodiversity: An outline of higher-level classification and survey of taxonomic richness (Addenda 2013). Zootaxa 3703: 27-33. doi: 10.11646/zootaxa.3703.1.7

Kury AB, Barros CM (2014) A new genus and eight new species of Amazonian cosmetines (Opiliones, Laniatores, Cosmetidae). Zoological Studies 53: 1-46. doi: 10.1186/s40555-014-0024-4

Kury AB, Ferreira CP (2012) Two new species of Roquettea MelloLeitão, 1931 from northern Brazil (Opiliones: Laniatores: Cosmetidae). Zootaxa 3328: 35-46.

Kury AB, PinTo-DA-Rocha R (2007) Cosmetidae, p. 182-185. In: Machado G, Pinto-da-Rocha R, Giribet G (Eds.) Harvestmen, the biology of Opiliones. Cambridge, Harvard University Press, $\mathrm{x}+597 \mathrm{p}$.

Kury AB, Villarreal OM, Sampaio C (2007) Redescription of the type species of Cynorta (Arachnida, Opiliones, Cosmetidae). Journal of Arachnology 35(2): 325-333. doi: 10.1636/H0635.1

Kury AB, Villarreal OM (2015) The prickly blade mapped: establishing homologies and a chaetotaxy for macrosetae of penis ventral plate in Gonyleptoidea (Arachnida, Opiliones, Laniatores). Zoological Journal of the Linnean Society 174: 1-46. doi: 10.1111/zoj. 12225

Mello-Leitão CF (1932) Opiliões do Brazil. Revista do Museu Paulista 17(2): 1-505.

MelLo-Leitão CF (1933) Notas sobre os opiliões do Brasil descritos na obra póstuma de Sörensen: "Descriptiones Laniatorum". Boletim do Museu Nacional 9(1): 99-114.

Mello-Leitão CF (1940) Quatro novos gêneros de Laniatores do Brasil. Papéis avulsos do Departamento de Zoologia 1: 39-42.

Mello-Leitão CF (1942) Oito novos opiliões do Espírito Santo. Boletim do Museu Nacional 14(17): 3-11.

Pекту M (1833) Delectus animalium articulatorum, quae in itinere per Brasilian annis 1817-1820 perecta aollegerum J.B. of Spix et of Martius. Monachii, 224p.

Pickard-Cambridge FO (1904) Opiliones, p. 545-560. In: Godman FD, SAlvin O (Eds.) Biologia Centrali-Americana, Arachnida, Araneidea and Opiliones. London, R.H. Porter/Dulau, vol. 2.

Pickard-Cambridge FO (1905) Order Opiliones, p. 561-610. In: Godman FD, Salvin O (Eds.). Biologia Centrali-Americana, Arachnida. Araneidea and Opiliones. London, R.H. Porter/ Dulau, vol. 2.

PINTO-DA-Rocha R (1997) Systematic review of the neotropical family Stygnidae (Opiliones, Laniatores, Gonyleptoidea). Arquivos de Zoologia 33(4): 163-342.

Pinto-Da-Rocha R, HaRa MH (2011) Redescription of Platygyndes Roewer 1943, a false Gonyleptidae (Arachnida, Opiliones, Cosmetidae). Zookeys 143: 1-12. doi: 10.3897/zookeys.143.1916

Pinto-DA-Rocha R, Yamaguti H (2013) Paecilaema batman, a new species of Brazilian troglophilous harvestman that exhibits a remarkable color patches variation (Opiliones: Cosmetidae). Zoologia 30(4): 441-446. doi: 10.1590/S1984-46702013000400011 
Pinto-da-Rocha R, Bragagnolo C, Marques FPlM, Antunes Junior M (2014) Phylogeny of harvestmen family Gonyleptidae inferred from a multilocus approach (Arachnida: Opiliones). Cladistics 30: 519-539. doi: 10.1111/cla.12065

Ringuelet RA (1959) Los Aracnidos argentinos del orden Opiliones. Revista del Museo Argentino de Ciencias Naturales "Bernardino Rivadavia" (Zoologia) 5: 126-439.

Roewer CF (1912) Die Familie der Cosmetiden OpilionesLaniatores. Archiv für Naturgeschichte 78(10): 1-122.

Roewer CF (1916) 7 neue Opilioniden des Zoolog. Museums in Berlin. Archiv für Naturgeschichte 81(12): 613.

Roewer CF (1923) Die Weberknechte der Erde. Systematische Beardeitung der bisher bekannten Opiliones. Jena, Gustav-Ficher, 1116p.

RoEWER CF (1927) Weitere Weberknechte II. (2. Ergänzung der Weberknechte der Erde, 1923). Abhandlungen der Naturwissenschaftlichen Verein zu Bremen 26(3): 527-632.

Roewer CF (1947) Diagnosisn neuer Gattungen und Arten der Opiliones - Laniatores. Weitere Weberknechte XII. Cosmetidae. Senckenbergiana 28(1-3): 1-58.

SiLHAVY V (1971) A further new genus and species of cosmetid from the Antilles: Arucillus hispaniolicus gen. n., sp. nov. (Arachnoidea, Opilionidea). Acta Entomologica Bohemoslovaca 68(2): 138140.

Submitted: 7 April 2015

Received in revised form: 16 July 2015

Accepted: 11 August 2015

Editorial responsibility: Ângelo Parise Pinto
SIMON E (1880) Premier supplément au travail intitulé essai d'une classification des Opiliones Mecostethi, etc (première Partie). Comptes rendus des Seances de la Société Entomologique de Belgique 1880: 100-103.

SOARES BAM, SOARES HEM (1946) Um novo gênero e duas novas espécies de opiliões (Opiliones - Cosmetidae, Gonyleptidae). Papéis Avulsos do Departamento de Zoologia 7(19): 227- 232.

SoAres HEM, SoAres BAM (1987) Opera Opiliologica Varia XVIII. (Opiliones, Cosmetidae e Gonyleptidae). Revista Brasileira de Entomologia 31(1): 1-11.

SøRENSEN W (1884) Opiliones Laniatores (Gonyleptides W. S. olim). Musei Hauniensis. Naturhistorisk Tidsskrift 14(3): 555-646.

Townsend Jr VR, Víquez C, Vanzandt PA, Proud DN (2010) Key to the Species of Cosmetidae (Arachnida, Opiliones) of Central America, with Notes on Penis Morphology and Sexual Dimorphisms. Zootaxa 2414: 1-26.

Walker EA, TOWnsend JR VR (2014) Ovipositor Morphology of Cosmetid Harvestmen (Arachnida, Opiliones, Laniatores): A New Source of Informative Characters. Journal of Morphology 275(12): 1376-85. doi: 10.1002/jmor.20310

WWF (2015) Choco-Darien moist forests. World Wide Fund for Nature. Available online at: http://wwf.panda.org/ about_our_earth/ecoregions/chocodarien_moist_forests.cfm [Accessed: 07/07/2015] 